\title{
Experimental Investigation on Chloride Diffusion Coefficient of Self-compacting Concrete in the Oman Sea
}

\author{
Naser Nosratzehi', Mahmoud Miri ${ }^{1 *}$ \\ ${ }^{1}$ Department of Civil Engineering, University of Sistan and Baluchestan, P.O. Box 9816745563-161, Daneshgah Boulevard, \\ Zahedan, Iran \\ * Corresponding author, e-mail: mmiri@eng.usb.ac.ir
}

Received: 26 November 2019, Accepted: 30 March 2020, Published online: 06 May 2020

\begin{abstract}
Chloride ion penetration is an important parameter influencing the service life of a concrete structure, especially in aggressive environments. Severe chloride-induced corrosion of reinforced concretes has been reported in the southern part of Iran in the region of Oman Sea. In this paper, the effect of different environmental conditions of the Oman Sea on chloride penetration and mechanical properties of self-compacting concrete (SCC) and normal concrete (NC) is investigated. For this purpose, a number of prismatic specimens were exposed to various environmental conditions such as tide, submersion and atmospheric conditions. Surface chloride concentration and diffusion coefficient of SCC in these zones were calculated based on Fick's second law, at 28, 90 and 150 days and compared with NC. Based on the values obtained in this study, relationships are proposed for concrete permeability and surface chloride of self-compacting concrete (SCC) at different ages in different aggressive environments. By determining the corrosion time based on these relations, it is observed that for a given water-to-cement ratio, the self-compacting concrete (SCC) has higher durability compared to normal concrete (NC).
\end{abstract}

Keywords

concrete, durability, diffusion, empirical model, Oman Sea

\section{Introduction}

Concrete, a composite material mainly composed of cement, aggregate and water uses approximately 20 billion tons of raw materials annually [1]. So, production of concrete with high durability is so important. The durability of hardened concrete greatly depends on the quality and permeability of concrete [2]. Corrosion caused by chloride is one of the most common and serious causes of concrete deterioration that affects the durability of concrete $[3,4]$. In particular, chloride-induced corrosion is recognized to be the major cause of reinforced concrete deterioration subject to de-icing salts or located in marine environments $[5,6]$.

In marine conditions, the penetration of chloride ion into concrete and consequently the corrosion caused by its diffusion is the main cause of failure and shortening the service life of reinforced concrete structures. Hence, concrete structures situated in aggressive environments should be durable enough to withstand various aggressive factors such as diffusion of chloride ions and corrosion. Costa and Appleton [7] studied chloride penetration into concrete using fifty-four concrete specimens that were exposed to the marine environment for 3-5 years. In their research, three concrete mixes and five different exposure conditions were studied. Results indicated that both concrete diffusion coefficient and surface chloride is time-dependent.

Song et al. [8] showed that increasing the water-to-cement ratio leads to an increase in the diffusion coefficient of concrete. They also indicated that it is possible to reduce this coefficient by using additives with hydrating capacities. It was also revealed that diffusion coefficients of concrete and surface chloride are different in splash and tidal zones.

Moreover, the initial corrosion of reinforced concrete is mainly dependent on the chloride threshold penetration depth of concrete exposed to the marine environment. Cheewaket et al. [9] found that the threshold of chloride penetration depth increased more rapidly during the first five years, after which the rate of increase declined.

Valipour et al. [10] studied the penetration of chloride ion into concrete in various environmental conditions in the Persian Gulf. Results indicated that increasing the concrete density contributes to the enhancement of concrete 
durability in aggressive environments. Another study was performed by Safehian and Ramezanianpour [11] on the permeability of concrete in the Persian Gulf marine environment. Results indicated that the concrete diffusion coefficient $\left(D_{c}\right)$ depends on the concrete type and mix design.

Self-compacting concrete (SCC) is a particular type of concrete that can be placed and compacted under its own weight $[12,13]$. The use of SCC has become popular during the past decade [14]. SCC is needed for modern buildings [15] and can be used without a need for externally or internally induced vibration [16].

Some researchers have studied the mechanical properties of SCC mixes and compared the results with those of normal concrete (NC) mixtures [17-19]. Moreover, the durability of SCC has been studied by some researchers and the investigations indicated its excellent performance [20-26]. Tests used in these studies have included RCPT, water permeation, salt scaling resistance tests, chloride penetration and electrical, resistivity.

Calado et al. [27] compared the durability indicators of SCC and NC specimens in tropical coastal environments. The experiments developed in the laboratory at the construction site of the Pernambuco Arena. They showed that SCC presented better durability indicators than the normal concrete. The chloride diffusion factor was very low in the SCC samples at both 28 and 90 days. In other research, Rao et al. [28] investigated the mechanical properties and durability of self-compacting. They showed that the SCC mixes performed better than $\mathrm{NC}$ in the corrosion parameters.

da Silva and de Brito [29] examined the durability performance of self-compacting concrete. Results indicate that the penetration of chloride ion in SCC is affected by the amount of mineral additives. Nielsen and Geiker [30] proposed a model based on Fick's second law for prediction of the diffusion coefficient of chloride ion. In a study by Ghods et al. [31] the maximum diffusion coefficient of chloride ion $\left(D_{c}\right)$ and concentration of surface chloride $(C)$ were obtained from the tide and splash zones, respectively.

Lin et al. [32] introduced a numerical model based on the finite element method for prediction of the service life of structures exposed to chloride environments. They used a model to study the effects of parameters such as humidity, temperature, and concentration of chloride ion. Wang and Lee [33] proposed a model for the penetration of chloride ion into concrete containing fly ash. In their model, concrete behavior was assessed based on chloride ion penetration and hydration models.
Ryan and O'Connor [34] utilized the results of chloride diffusion testing and probabilistic deterioration modeling to compare the predicted time of initiation of corrosion for self-compacting concretes. Kim et al. [35] investigated chloride diffusion in marine conditions. It was confirmed that the chloride diffusion factor was sensitive to environmental conditions. Also, they found that the time of corrosion can be evaluated in each zone using the error function solution and modified physical model.

The Oman Sea is experiencing a more intense crisis compared to other seas around the globe due to its corrosive nature. The Southern coasts of Iran impose high annual financial losses to the economy of this country due to problems associated with the composition of concrete are not durable enough [36]. Therefore, more research on the durability of concrete seems more necessary, as many concrete structures are to be built in this area.

Most of the aforementioned studies [7-10,30-33,37-40] addressed the diffusion coefficient only for normal concrete. In addition, most of the samples were built, cured, and tested in lab conditions. The authors couldn't find any research with samples cured in the real conditions in southeast Iran, especially on self-compacting concrete in the Oman Sea.

The aim of this study is to investigate chloride penetration and mechanical properties of self-compacting concrete and normal concrete under different environmental conditions in Chabahar Port, which is located in southeastern Iran, north of Oman Sea.

\section{Experimental programs \\ 2.1 Materials}

Ordinary Portland Cement (OPC), type II, according to ASTM C150 [41], were used in this study. The specific surface area of cement was $2900 \mathrm{~cm}^{2} / \mathrm{g}$, and chemical analysis of cement as presented in Table 1. River sand as fine aggregate with fineness modulus of 3 , specific gravity of $2.57 \mathrm{~g} / \mathrm{cm}^{3}$, and water absorption of $1.5 \%$ were used in this study. Moreover, crushed limestone as coarse aggregate with a maximum nominal diameter of $19 \mathrm{~mm}$, the specific gravity of $2.52 \mathrm{~g} / \mathrm{cm}^{3}$ and water absorption of $0.9 \%$ were used. The grading of fine and coarse aggregates is presented in Fig. 1 and compared with ASTM C33 [42] requirements. Moreover, superplasticizers or High Range Water Reducers (HRWR) according to Type G of ASTM C 494 [43] were utilized. 


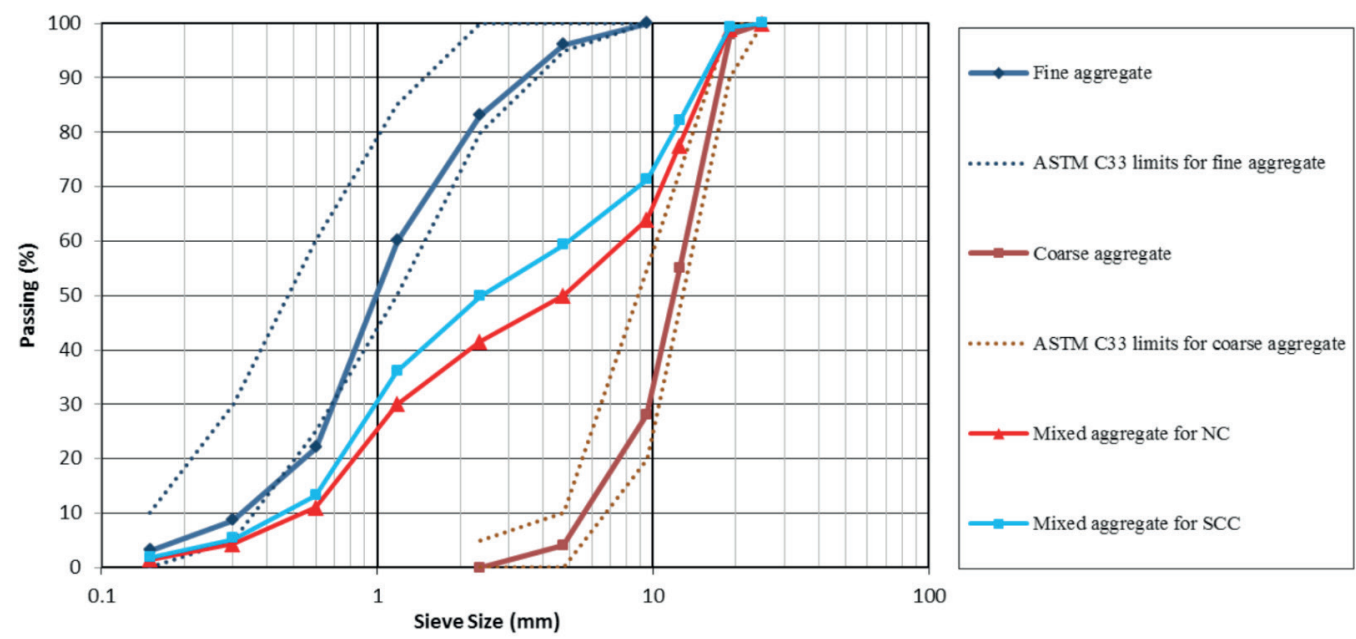

Fig. 1 Grading of aggregates and comparison with ASTM C33 requirements

Table 1 Chemical composition of cement (\%)

\begin{tabular}{cccccccc}
\hline $\mathrm{CaO}$ & $\mathrm{SiO}_{2}$ & $\mathrm{Al}_{2} \mathrm{O}_{3}$ & $\mathrm{Fe}_{2} \mathrm{O}_{3}$ & $\mathrm{MgO}$ & $\mathrm{SO}_{3}$ & $\mathrm{~K}_{2} \mathrm{O}$ & $\mathrm{NaO}_{2}$ \\
\hline 64 & 21.5 & 5 & 3.8 & 3 & 1.6 & 0.6 & 0.5 \\
\hline
\end{tabular}

\subsection{Mixture proportions}

$\mathrm{NC}$ and SCC mixtures were the same in terms of materials but mixed with different ratios. The main difference between $\mathrm{NC}$ and $\mathrm{SCC}$ mixes was in the coarse aggregate content; SCC had less coarse aggregate content $\left(660 \mathrm{~kg} / \mathrm{m}^{3}\right)$ compared to $\mathrm{NC}\left(902 \mathrm{~kg} / \mathrm{m}^{3}\right)$. SCC and $\mathrm{NC}$ mix designs are presented in Table 2 .

\subsection{Specimen preparation, casting and curing}

In this study, two types of specimens including cubic and prismatic specimens were prepared to investigate the effect of environmental conditions. Compressive strength tests were conducted at the ages of 28,90 and 150 days on cubic specimens with side lengths of $150 \mathrm{~mm}$. Prismatic specimens of size $150 \mathrm{~mm} \times 150 \mathrm{~mm} \times 500 \mathrm{~mm}$ for in-situ chloride penetration investigations were cast.

Two specimens for each type of concrete were made for different exposure conditions. After the curing phase, to achieve one-dimensional penetration of the chloride ion in the diffusion test, the other lateral surfaces of samples were coated with polyurethane-based epoxy (Fig. 2). This material is resistant to the aggressive environment of the Oman Sea.

For in-situ exposure conditions, after a week of moisture-curing in the laboratory, specimens were transferred to the durability research site (Fig. 3) and exposed to the following three conditions: submersion, tidal and atmospheric. Some of the cubic specimens were continued moisture curing in the laboratory.

\begin{tabular}{ccccccc}
\multicolumn{8}{c}{ Table 2 Concrete mix design $\left(\mathrm{kg} / \mathrm{m}^{3}\right)$} \\
\hline $\begin{array}{c}\text { Mix } \\
\text { Design }\end{array}$ & Sand & Gravel & Cement & Water & Limestone & HRWRA \\
\hline NC & 902 & 902 & 425 & 170 & - & 0.4 \\
SCC & 993 & 660 & 425 & 170 & 150 & 2.9 \\
\hline
\end{tabular}

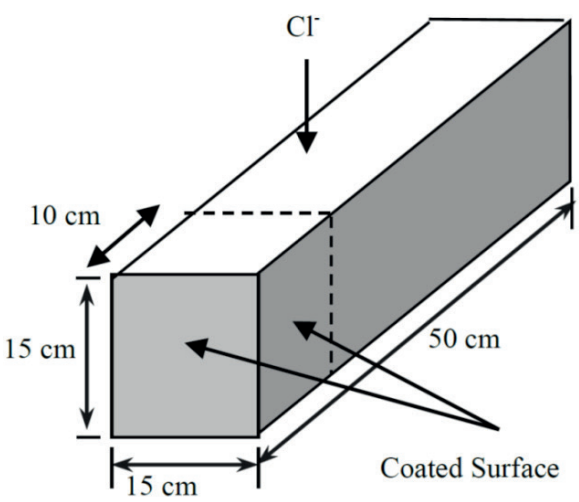

Fig. 2 Typical concrete prism specimen and preparing the slice for powder sample

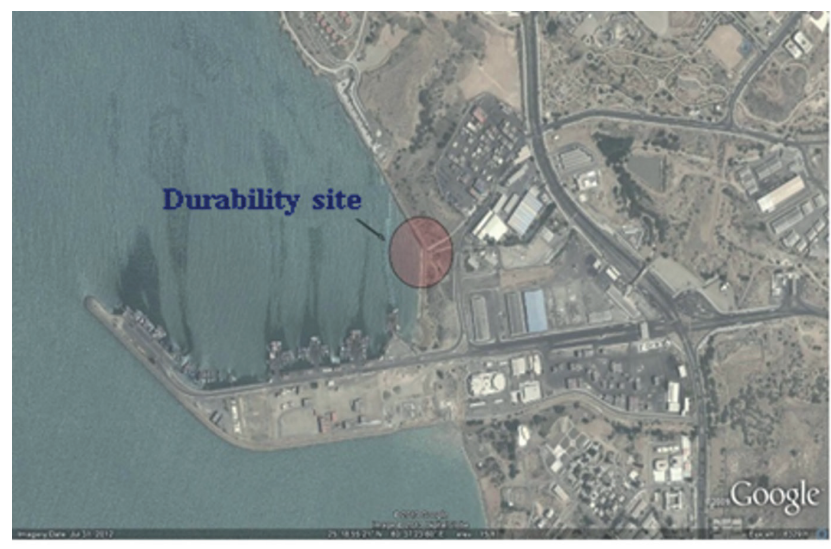

Fig. 3 Location of the concrete durability research site, the Oman Sea (Chabahar Port) 
Moreover, two cylindrical specimens with a height and diameter of $10 \mathrm{~cm}$ were prepared from each mix design to determine the concrete permeability according to NT Build 443 standard [44] for laboratory conditions. As instructed by the standard, the test samples were cured in saturated limewater for 28 days in a laboratory environment. After curing, the test specimens were removed out of the water and prepared as instructed by the NT Build 443 . The specimens were then cured in saltwater with a concentration of 16.5 wt.\% for 35 days, after which their chloride ion profiles were determined.

\subsection{Exposure conditions}

Table 3 shows the mean monthly temperature and relative humidity of the Chabahar port (located in the Oman Sea) [45]. The specimens were exposed to three types of exposure environments including tidal, submerge and atmospheric, on Chabahar port (Fig. 3) for different exposure time (28, 90 and 150 days).

Table 4 compares the chemical properties of the Oman Sea with other seas [46]. As can be seen, the Oman Sea has more chloride ions.

\subsection{Sampling and testing}

At the ages of 28, 90 and 150 days, chloride diffusion was determined in prismatic specimens. Each time, $100 \mathrm{~mm}$ was cut from the end of the prisms. The cut section of the remaining part was coated, as shown in Fig. 2, and the specimen was moved back to the exposure conditions.

A hole with a nominal diameter of $45 \mathrm{~mm}$ was drilled from the finished surface of the slice to an estimated depth of chloride penetration.
Powders were collected from different layers of concrete surfaces and analyzed separately for measuring the content of acid-soluble chloride, according to ASTM C1152 [47] and ASTM C114 [48].

\subsection{Chloride diffusion}

The penetration of chloride ion into the concrete members can be expressed by Fick's second law as [49]

$$
\frac{\partial C}{\partial T}=D_{C}\left(\frac{\partial^{2} C}{\partial x^{2}}\right)
$$

The Eq. (2) is the solution of the above differential equation:

$$
C(x, t)=C_{s} \times\left(1-\operatorname{erf}\left(\frac{x}{2 \sqrt{D_{c} t}}\right)\right),
$$

where $x$ denotes the distance from the concrete surface (meter), $t$ is the exposure duration (second), $D_{c}$ is the diffusion coefficient $\left(\mathrm{m}^{2} / \mathrm{s}\right) . C_{s}$ shows the weight percentage of concentration of chloride on the concrete surface, and $C(x, t)$ is the weight percentage of chloride ion in a depth of $x$ from the surface during time $t$. Moreover, erf is the error function which is expressed as follow:

$\operatorname{erf}(x)=\frac{2}{\sqrt{\pi}} \int_{0}^{x} e^{-\beta^{2}} d \beta$.

To estimate the diffusion coefficient $D_{c}$ and the surface chloride $C_{s}$, firstly, the concentration of chloride $\left(C_{L}\right)$ at different concrete depths of the prepared samples should be determined according to powder making and titration test. For this purpose, chloride ion profiles were measured at nine depths of NC and SCC samples. Then, $D_{c}$ and $C_{s}$ values were obtained by using the fitting toolbox of Matlab.

\begin{tabular}{|c|c|c|c|c|c|c|c|c|c|c|c|c|c|}
\hline Zone & Jan. & Feb. & Mar. & Apr. & May & Jun. & Jul. & Aug. & Sep. & Oct. & Nov. & Dec. & Annual \\
\hline Mean temperature $\left({ }^{\circ} \mathrm{C}\right)$ & 19.9 & 20.9 & 23.6 & 26.8 & 29.8 & 31.4 & 30.8 & 29.5 & 28.8 & 27.6 & 24.5 & 21.6 & 26.3 \\
\hline Mean relative humidity (\%) & 62 & 68 & 72 & 73 & 75 & 78 & 79 & 80 & 78 & 75 & 68 & 63 & 72 \\
\hline
\end{tabular}

Table 3 Mean temperature and relative humidity of Chabahar port in different months of the year

Source: Iran Meteorological Organization website [45]

\begin{tabular}{|c|c|c|c|c|c|c|}
\hline Content & Baltic Sea [46] & Atlantic Sea [46] & North Sea [46] & Mediterranean Sea [46] & Persian Gulf [46] & Oman Sea* \\
\hline $\mathrm{Ca}^{2+}$ & 190 & 410 & 430 & 470 & 430 & 401 \\
\hline $\mathrm{Mg}^{2+}$ & 600 & 1500 & 1330 & 1780 & 1460 & 1519 \\
\hline $\mathrm{SO}_{4}{ }^{2-}$ & 1250 & 2540 & 2780 & 3060 & 2720 & 3336 \\
\hline $\mathrm{Na}^{+}$ & 4980 & 9950 & 11050 & 11560 & 12400 & 13800 \\
\hline $\mathrm{Cl}^{-}$ & 8960 & 17830 & 19890 & 21380 & 21450 & 21625 \\
\hline Salt & 16200 & 32600 & 35900 & 38700 & 38900 & 39331 \\
\hline
\end{tabular}

Table 4 Chemical analysis of the water of the Oman Sea -Chabahar Port as compared to water of other seas (mg/l)

* From chemical test results 


\section{Results and discussion}

\subsection{Compressive strength}

Summary of the compressive test results for cubic samples, after being exposed to the aforementioned environments, is presented in Table 5. The results are prepared for three different ages (28, 90 and 150 days). Each value is the average of three compressive measurements. As can be seen from Table 5, SCC concrete showed higher strength than normal concrete in different environments.

The strength of the SCC specimens cured under laboratory, submerged, tidal, and atmospheric conditions at the age of 150 days was $50.2,43.9,49.5$, and 47.1 $\mathrm{MPa}$, respectively, while these values were 48.1, 41.5, 46.5, and 44.2 $\mathrm{MPa}$ for the NC. As shown, the SCC results in a lower decrease in strength compared to $\mathrm{NC}$ at high ages. However, the trend of strength variations in SCC under different environments is similar to compressive strength in NC. On the other hand, under atmospheric conditions, the compressive strength of concrete is lower compared to submerged and tidal conditions.

\subsection{Chloride diffusion profiles}

\subsubsection{Laboratory exposure}

The test results obtained according to the NT Build 443 standard are presented in Table 6 to determine the permeability and concentration of chloride ions on the studied mix designs under laboratory conditions.

As shown in Table 6, the permeability of SCC specimens is lower compared to the $\mathrm{NC}$, which is due to the high compactness of the SCC. Reducing the nominal maximum size of aggregates and using mineral powder as filler to modify the mix design reduces the permeability and increases the durability of SCC.

Table 5 Results of the compressive strength test (MPa)

\begin{tabular}{lcccccc}
\hline & \multicolumn{2}{c}{28 days } & \multicolumn{2}{c}{90 days } & \multicolumn{2}{c}{150 days } \\
\hline Zone & NC & SCC & NC & SCC & NC & SCC \\
Laboratory & 40.3 & 41.5 & 43.5 & 46.2 & 48.1 & 50.2 \\
Atmosphere & 36.6 & 38.6 & 38.1 & 40.5 & 41.5 & 43.9 \\
Submerge & 40.3 & 41.1 & 43.1 & 45.1 & 46.5 & 49.5 \\
Tidal & 38.6 & 39.8 & 40.9 & 43.2 & 44.2 & 47.1 \\
\hline
\end{tabular}

Table 6 Apparent chloride diffusion coefficient and surface chloride concentration in the laboratory

\begin{tabular}{lcc}
\hline Concrete type & $D_{c}\left(\times 10^{-12}\right)\left(\mathrm{m}^{2} / \mathrm{s}\right)$ & $C_{s}(\%$ wt. of concrete $)$ \\
\hline NC & 9.5 & 0.87 \\
SCC & 7.4 & 0.85 \\
\hline
\end{tabular}

\subsubsection{Field exposure}

Chloride ion profiles obtained by fitting chloride concentrations at the corresponding depths of NC and SCC, as presented in Fig. 4.

The permeability and surface chloride for NC and SCC in different environments are presented in Table 7. The results obtained in each studied environment are discussed in the following.

\section{Atmospheric conditions}

In Figs. 5 and 6, the diffusion coefficient and surface chloride concentration for both the $\mathrm{NC}$ and $\mathrm{SCC}$ are compared in the atmospheric conditions. The surface chloride concentration for $\mathrm{NC}$ is about $0.054 \%$ and $0.08 \%$ at the ages of 28 and 150 days, respectively. Corresponding values

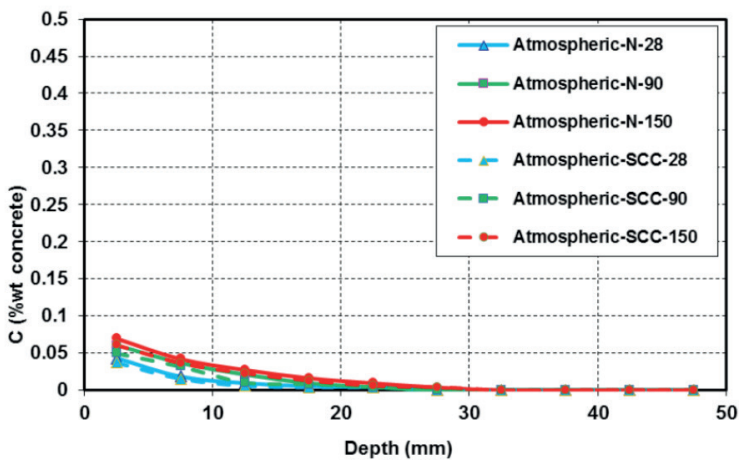

(a)

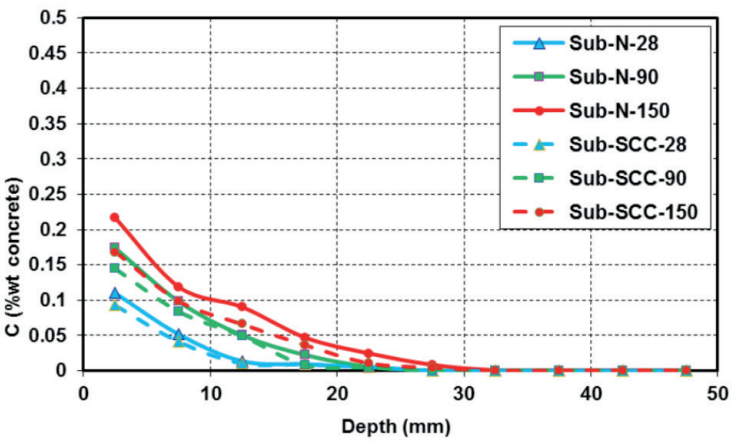

(b)

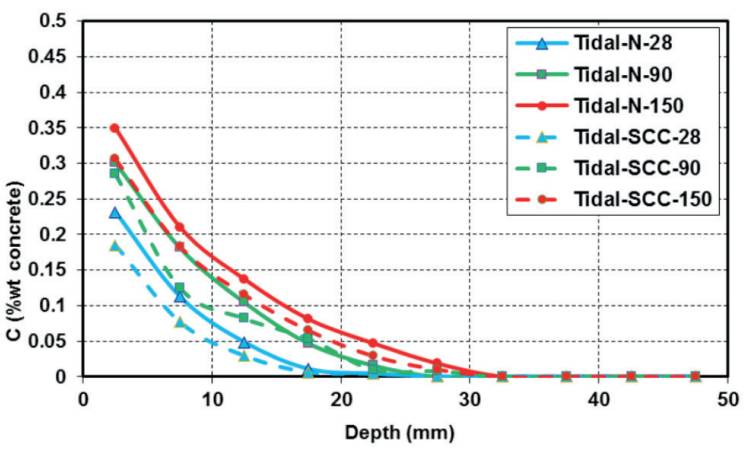

(c)

Fig. 4 Profiles of chloride ions of NC and SCC for different exposure conditions: (a) atmospheric; (b) submersion; (c) tidal 


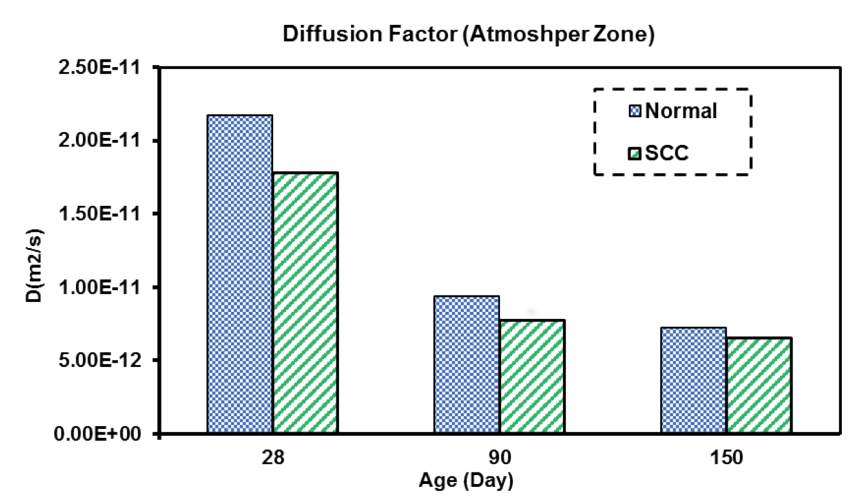

Fig. 5 Concrete diffusion coefficient at different ages in atmospheric conditions

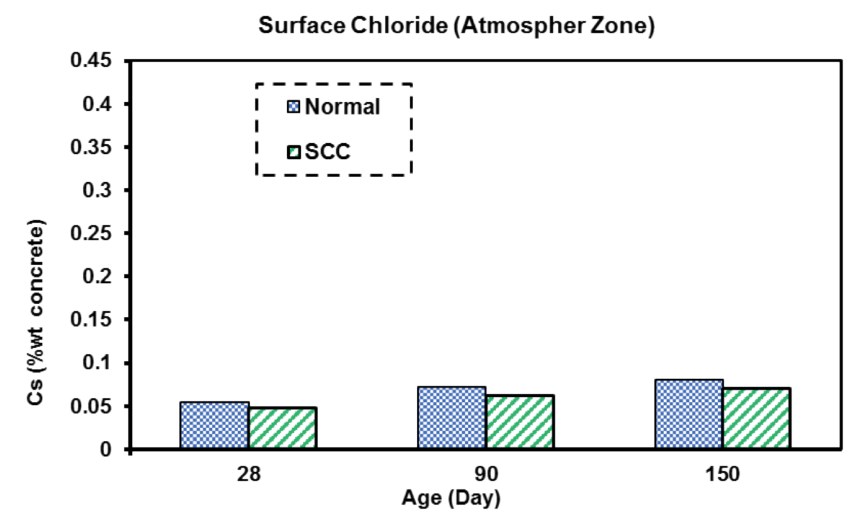

Fig. 6 Concrete surface chloride concentration at different ages in atmospheric conditions

for SCC is about $0.048 \%$ and $0.071 \%$ at the ages of 28 and 150 days, respectively. Based on the presented results, one can deduce that the diffusion coefficients for SCC are about $21 \%$ and $10 \%$ lower than $\mathrm{NC}$ at the ages of 28 and 150 days, respectively.

The concentration of the chloride ion in SCC is lower than $\mathrm{NC}$ in the atmospheric zone at similar times. Moreover, the results indicate that in the atmospheric zone, by increasing the time of exposure to an aggressive environment, the concentration of the surface chloride ion increases, whereas its diffusion coefficient decreases.

\section{Submersion conditions}

In Fig. 7, the diffusion coefficient for both the NC and SCC are compared in different ages. The diffusion coefficients for SCC are about $7 \%$ and $9 \%$ lower than $\mathrm{NC}$ at the ages of 28 and 150 days, respectively. As shown in Fig. 8, the surface chloride concentration in submersion conditions for SCC is about $17 \%$ and $25 \%$ lower than NC at the ages of 28 and 150 days, respectively.

The concentration of the surface chloride ion in the submerged zone in SCC at a given time is lower compared to that in NC. Moreover, the results show that in

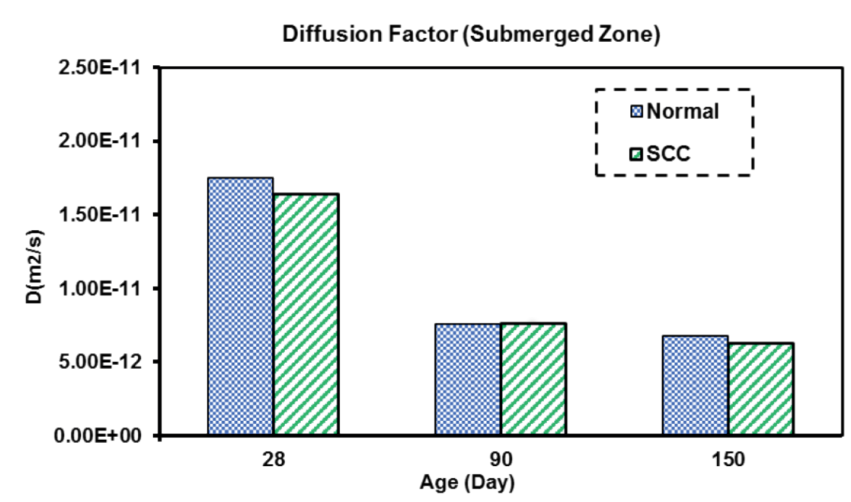

Fig. 7 Concrete diffusion coefficient at different ages in submersion conditions

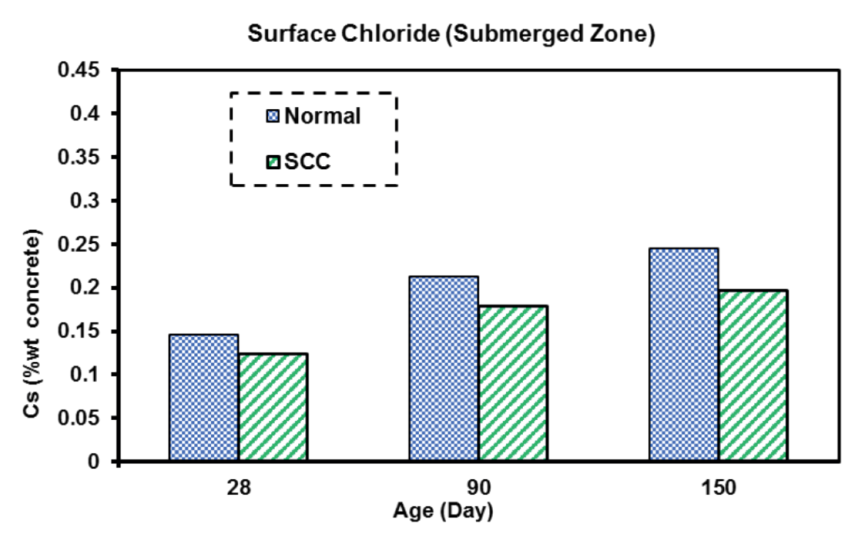

Fig. 8 Concrete surface chloride concentration at different ages in submersion conditions

the submerged zone, by increasing the exposure time, the concentration of surface chloride increases, whereas the diffusion coefficient of concrete decreases.

\section{Tidal conditions}

The diffusion coefficient and surface chloride concentration of tidal condition are shown in Figs. 9 and 10, respectively. According to summarized results in Table 7, values of diffusion coefficient $\left(D_{c}\right)$ for normal concrete samples in tidal condition at 28 and 150 days reduced to $20.71 \times 10^{-12} \mathrm{~m}^{2} / \mathrm{s}$ and $7.21 \times 10^{-12} \mathrm{~m}^{2} / \mathrm{s}$, respectively.

On the other hand, in this condition, the diffusion coefficient of SCC samples for 28 and 150 days were $16.05 \times 10^{-12} \mathrm{~m}^{2} / \mathrm{s}$ ( $25 \%$ lower than normal concrete) and $6.40 \times 10^{-12} \mathrm{~m}^{2} / \mathrm{s}(13 \%$ lower than normal concrete). This reflects better performance and higher durability of SCC in tidal conditions.

In tidal zone, the concentration of surface chloride on SCC was lower at all ages. Moreover, surface chloride concentration reached from $0.298 \%$ to $0.398 \%$ from the age of 28 days to the age of 150 days. However, the surface chloride concentration at the same ages of SCC reached from $0.248 \%$ to $0.357 \%$. 


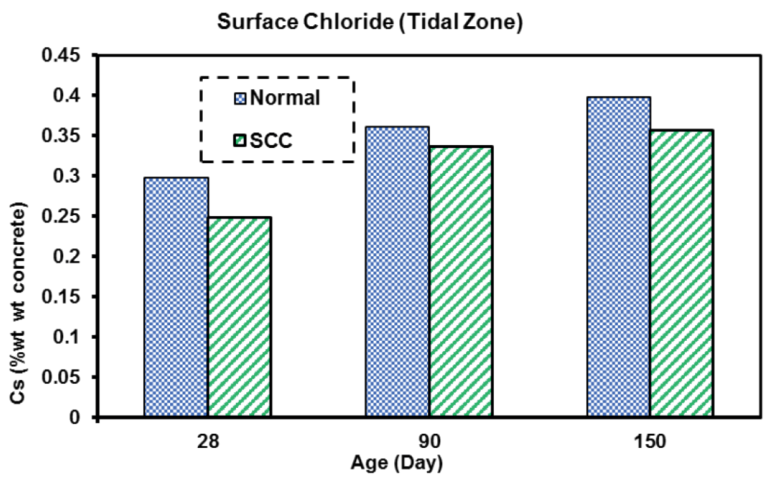

Fig. 9 Concrete diffusion coefficient at different ages in tidal conditions

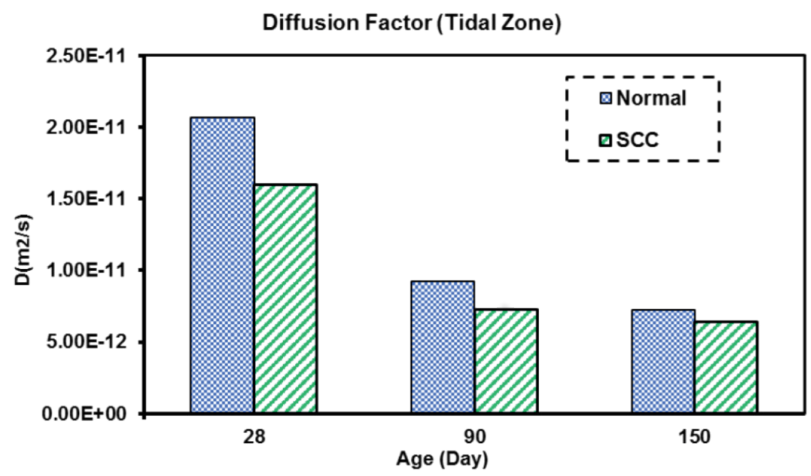

Fig. 10 Concrete surface chloride concentration at different ages in tidal conditions

Results show that the normal concrete has a higher diffusion coefficient in tidal, submersion and atmospheric conditions at all ages in the order of appearance. In most samples for all exposure conditions, due to the continuity of cement hydration, the microstructure of concrete was enhanced and the value of the diffusion coefficient was reduced.

\subsection{Time to corrosion}

The solution for the Fick's 2nd law of diffusion (Eq. 2) was used to model the permeation of chloride ion in concrete under submerged, tidal, and atmospheric conditions $[50,51]$. According to the results, the concentration of the surface chloride ion and the permeability coefficient of the concrete change over time. Therefore, the time variations should be taken into account when modeling the permeation of chloride ion.
Eq. (4) was used in most modeling procedures to take into account the variations of chloride ion diffusion over time $[35,50,51]$.

$D_{a}(t)=D_{r e f}\left(\frac{t_{r e f}}{t}\right)^{m}$

In this relationship, $D_{\text {ref }}$ is the diffusion coefficient for the chloride ion obtained from the NT Build 443 test, $t_{\text {ref }}$ is the time corresponding to the diffusion coefficient $D_{\text {ref }}$ (equal to 28 days), $t$ is the age of concrete, and $m$ is the age factor of concrete.

The results from published researches show that the long-term results should also be used to determine the age factor of concrete. Based on the permeability coefficient values obtained for SCC and NC under laboratory conditions at the age of 28 days as well as the field results, the age factor $(m)$ was assumed to be 0.2 in the modeling process in the Life365 software [52]. Assuming this value for age factor, Eq. (4) can be used to almost accurately predict the permeability values in Table 7 based on the results of the NT Build 443 test.

Various relationships have been proposed to take into account the variations in the concentration of surface chloride ion [35, 50, 52]. In Life365 software [52], the concentration of surface chloride ion is considered to vary linearly with time. However, the results reported by Wu et al. [50] and Kim et al. [35] suggest that Eq. (5) is more consistent with the results measured from specimens exposed to submerged, tidal, and atmospheric conditions.

$C(t)=C_{0} t^{n}$

In this relation, $C(t)$ is the weight percentage of chloride ion with respect to concrete, $t$ is the duration of exposure to chloride, and constants $C_{0}$ and $n$ are obtained by fitting the curve on the measured concentration of surface chloride ion at different times. Therefore, the parameters $C_{0}$ and $n$ were determined by curve fitting Eq. (5) using the results from the measurement of concentration of surface chloride ion. The results were presented in Table 8 for each of the atmospheric, submerged, and tidal conditions.

Table 7 Apparent chloride diffusion coefficient and surface chloride concentration in field exposure

\begin{tabular}{|c|c|c|c|c|c|c|c|c|c|c|c|c|}
\hline \multirow{3}{*}{$\begin{array}{l}\text { Days } \\
\text { Concrete type }\end{array}$} & \multicolumn{6}{|c|}{$D_{c}\left(\times 10^{-12}\right)\left(\mathrm{m}^{2} / \mathrm{s}\right)$} & \multicolumn{6}{|c|}{$C_{s}$ (\% wt. of concrete) } \\
\hline & \multicolumn{2}{|c|}{28} & \multicolumn{2}{|c|}{90} & \multicolumn{2}{|c|}{150} & \multicolumn{2}{|c|}{28} & \multicolumn{2}{|c|}{90} & \multicolumn{2}{|c|}{150} \\
\hline & $\mathrm{NC}$ & SCC & $\mathrm{NC}$ & $\mathrm{SCC}$ & $\mathrm{NC}$ & SCC & $\mathrm{NC}$ & $\mathrm{SCC}$ & $\mathrm{NC}$ & SCC & $\mathrm{NC}$ & $\mathrm{SCC}$ \\
\hline Atmosphere & 21.70 & 17.83 & 9.36 & 7.73 & 7.21 & 6.55 & 0.054 & 0.048 & 0.072 & 0.062 & 0.08 & 0.071 \\
\hline Submerge & 17.52 & 16.42 & 7.57 & 7.59 & 6.79 & 6.24 & 0.146 & 0.124 & 0.213 & 0.179 & 0.245 & 0.196 \\
\hline Tidal & 20.71 & 16.05 & 9.24 & 7.30 & 7.21 & 6.40 & 0.298 & 0.248 & 0.361 & 0.337 & 0.398 & 0.357 \\
\hline
\end{tabular}


Table 8 Parameters of $C_{0}$ and $n$

\begin{tabular}{lcccc}
\hline \multicolumn{1}{c}{$\begin{array}{c}\text { Storage } \\
\text { condition }\end{array}$} & NC & SCC & NC & SCC \\
\hline Atmosphere & 0.0267 & 0.0248 & 0.2149 & 0.2113 \\
Submerge & 0.0676 & 0.0644 & 0.2532 & 0.2829 \\
Tidal & 0.1874 & 0.1386 & 0.1564 & 0.2028 \\
\hline
\end{tabular}

By applying the finite difference method and based on Eqs. (2), (4) and (5), and the use of concrete permeability and concentration of surface chloride ion obtained from NT Build 443 standard test, chloride ion penetration profile was modeled. Then, the beginning of the rebar corrosion process at a depth of $5 \mathrm{~cm}$ in $\mathrm{SCC}$ and $\mathrm{NC}$ specimens was investigated. Fig. 11 compares the results obtained from the model and the experimental results, indicating good consistency between them.

Note that the corrosion process is started when the concentration of the chloride ion reaches the critical concentration level $[35,50,52,53]$. Time to corrosion initiation results is presented in Table 9. Note that the critical chloride ion concentration was considered to be $0.05 \mathrm{wt} \%$ of concrete [53].

The corrosion initiation time obtained from the modeling is compared with the outputs of the Life365 software in Table 9. The corrosion in the model of NC under submerged and tidal conditions started sooner compared to Life 365, which is due to assuming an identical age factor related to the difference in the variations of concentration of surface chloride ion. Note that in Life365 software, the finite difference method is used to solve the diffusion equation. However, the corrosion occurs sooner for the NC under atmospheric conditions in the Life365 software compared to the prepared model in this study. The reason for this can be attributed to the difference in variations of concentration of surface chloride ion over time. Investigating of the corrosion initiation time indicates that $\mathrm{NC}$ experiences corrosion sooner than SCC. The corrosion initiation time in SCC under tidal, submerged, and atmospheric conditions is longer than $\mathrm{NC}$ by a factor of $1.65,1.45$, and 2.03 , respectively. For the same water-to-cement ratio in both SCC and NC, these differences can be attributed to the application of mineral powder in SCC species which reduces the concrete permeability. The decrease in permeability is due to the filling of the concrete porosities by mineral powder, which are shown by Sawicz and Heng [54], Ghafoori et al. [55], and Ramezanianpour et al. [56].

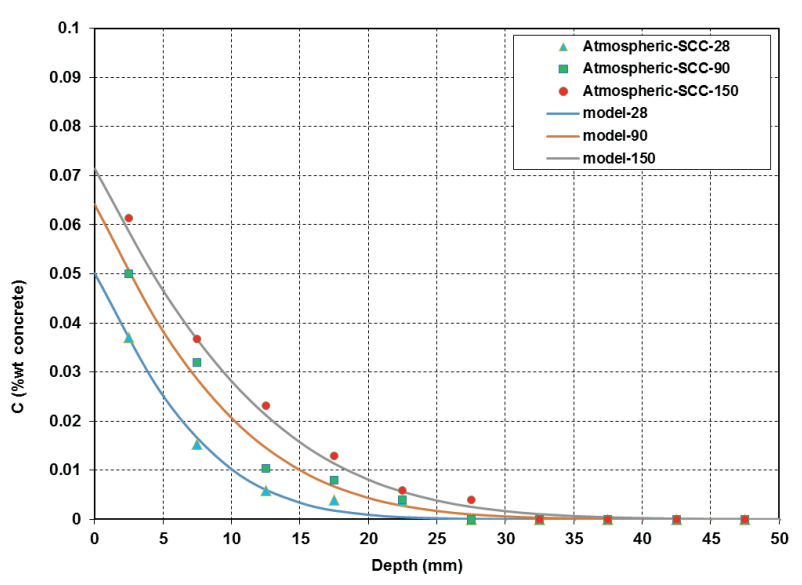

(a)

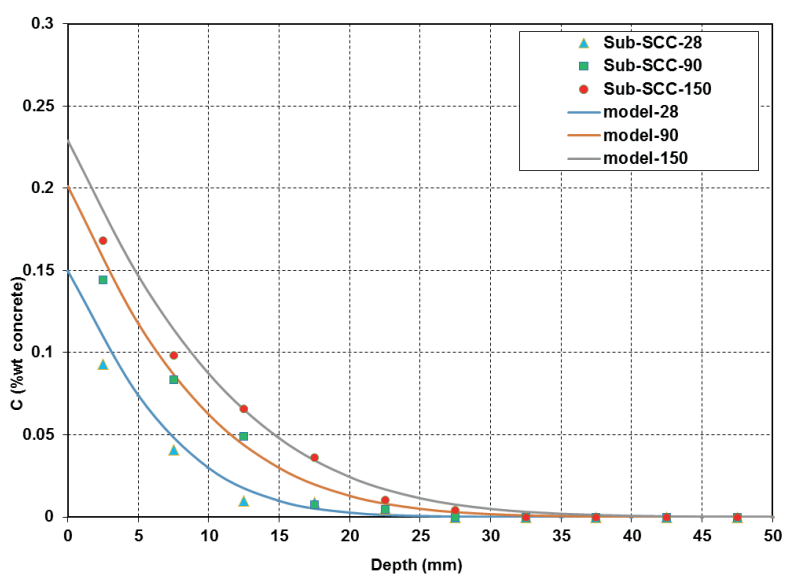

(b)

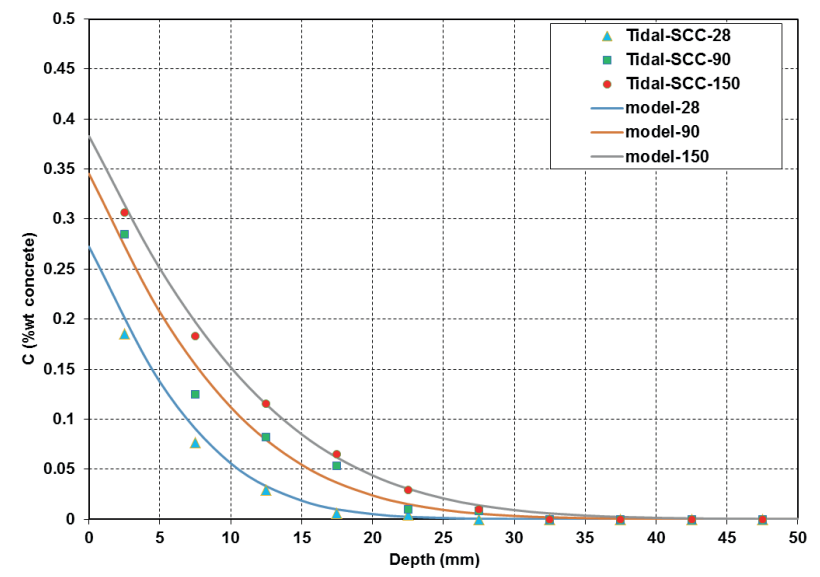

(c)

Fig. 11 Comparison of experimental results with model predictions for self-compacting concrete under different exposure conditions:

(a) atmospheric; (b) submersion; (c) tidal

The results indicate that the time to corrosion initial in tidal conditions is shorter than in atmospheric and submerged conditions. The corrosion beginning time for $\mathrm{NC}$ species under atmospheric and submerged conditions 
Table 9 Predicted time to reach critical chloride concentration $\left(C_{c r}\right)$ at $50 \mathrm{~mm}$ depth in each exposure zone

\begin{tabular}{lccc}
\hline $\begin{array}{l}\text { Storage } \\
\text { condition }\end{array}$ & $\begin{array}{c}\text { Time to reach } C_{c r} \text { (year) based on } \\
\text { the model }\end{array}$ & $\begin{array}{c}\text { Time to reach } \\
C_{c r} \text { (year) }\end{array}$ \\
\hline & NC & SCC & Life-365 \\
Atmosphere & 12.0 & 17.1 & 10.1 \\
Submerge & 3.4 & 5.1 & 3.6 \\
Tidal & 2.7 & 3.7 & 3.1 \\
\hline
\end{tabular}

was longer than it in tidal conditions by 4.4 and 1.3 times, respectively. Similarly, these factors were 4.6 and 1.4 times for SCC. The results obtained in this study are consistent with those reported by Kim et al. [35].

\section{Conclusions}

By analyzing three aggressive environments in the Oman Sea and their effects on the penetration of chloride ion into concrete, the following results were obtained in this research:

According to the test results, tidal is the most aggressive zone in terms of penetration of chloride ion into normal and SCC specimens.

Analysis of profiles of chloride ion reflects the satisfactory performance of SCC as compared to normal concrete in the Oman Sea.

\section{References}

[1] Abed, M., Nemes, R. "Mechanical Properties of Recycled Aggregate Self-Compacting High Strength Concrete Utilizing Waste Fly Ash, Cellular Concrete and Perlite Powders", Periodica Polytechnica Civil Engineering, 63(1), pp. 266-277, 2019.

https://doi.org/10.3311/PPci.13136

[2] Misák, P., Stavař, T., Rozsypalová, I., Kocáb, D., Pőssl, P. "Statistical view of evaluating concrete-surface-layer permeability tests in connection with changes in concrete formula", Materiali in Tehnologije, 51(3), pp. 379-385, 2017

https://doi.org/10.17222/mit.2015.223

[3] Kropp, J., Hilsdorf, H. K. (eds.) "Performance Criteria for Concrete Durability", 1st ed., CRC Press, London, UK, 1995.

https://doi.org/10.1201/9781482271522

[4] Neville, A. "Chloride attack of reinforced concrete: an overview", Materials and Structures, 28(2), pp. 63-70, 1995. https://doi.org/10.1007/BF02473172

[5] Bastidas-Arteaga, E., Chateauneuf, A., Sánchez-Silva, M., Bressolette, Ph., Schoefs, F. "A comprehensive probabilistic model of chloride ingress in unsaturated concrete", Engineering Structures, 33(3), pp. 720-730, 2011.

https://doi.org/10.1016/j.engstruct.2010.11.008

[6] McPolin, D., Basheer, P. A. M., Long, A. E., Grattan, K. T. V., Sun, T. "Obtaining progressive chloride profiles in cementitious materials", Construction and Building Materials, 19(9), pp. 666-673, 2005. https://doi.org/10.1016/j.conbuildmat.2005.02.015
The values of surface chloride and diffusion coefficient in submersion conditions also showed better performance on SCC. The diffusion coefficient of SCC on 28 days and 150 days were $10 \%$ and $15 \%$ lower than that of normal concrete, respectively. In the same conditions, the surface chloride concentration of self-compacting concrete on 28 days and 150 days were $18 \%$ and $52 \%$ lower than that of normal concrete, respectively.

The proposed equations to determine the amount of surface chlorine and the chloride diffusion factor of concrete are more accurate than the Life 365 software in normal and self-compacting concrete. By comparing experimental results with proposed models, the accuracy of each model is high and acceptable in different environments.

Investigating the initiation time of corrosion indicates that the time of corrosion of self-compacting concrete is longer than normal concrete. The time to corrosion in the tidal, submerged and atmospheric conditions of self-compacting concrete are 1.65, 1.45 and 2.03 times higher than normal concrete, respectively. In general, the results show that the use of self-compacting concrete in marine structures located in the Chabahar zone reduces permeability and improves the durability of chloride ion penetration.

[7] Costa, A., Appleton, J. "Chloride penetration into concrete in marine environment - Part I: Main parameters affecting chloride penetration", Materials and Structures, 32, pp. 252-259, 1999. https://doi.org/10.1007/bf02479594

[8] Song, H.-W., Lee, C.-H., Ann, K. Y. "Factors influencing chloride transport in concrete structures exposed to marine environments", Cement and Concrete Composites, 30(2), pp. 113-121, 2008. https://doi.org/10.1016/j.cemconcomp.2007.09.005

[9] Cheewaket, T., Jaturapitakkul, C., Chalee, W. "Initial corrosion presented by chloride threshold penetration of concrete up to 10 year-results under marine site", Construction and Building Materials, 37, pp. 693-698, 2012. https://doi.org/10.1016/j.conbuildmat.2012.07.061

[10] Valipour, M., Pargar, F., Shekarchi, M., Khani, S. "Comparing a natural pozzolan, zeolite, to metakaolin and silica fume in terms of their effect on the durability characteristics of concrete: A laboratory study", Construction and Building Materials, 41, pp. 879-888, 2013. https://doi.org/10.1016/j.conbuildmat.2012.11.054

[11] Safehian, M., Ramezanianpour, A. A. "Assessment of service life models for determination of chloride penetration into silica fume concrete in the severe marine environmental condition", Construction and Building Materials, 48, pp. 287-294, 2013. https://doi.org/10.1016/j.conbuildmat.2013.07.006 
[12] Nagaratnam, B. H., Faheem, A., Rahman, M. E., Mannan, M. A., Leblouba, M. "Mechanical and Durability Properties of Medium Strength Self-Compacting Concrete with High-Volume Fly Ash and Blended Aggregates", Periodica Polytechnica Civil Engineering, 59(2), pp. 155-164, 2015. https://doi.org/10.3311/PPci.7144

[13] Oualit, M., Irekti, A., Melinge, Y. "Saturation Point of Superplasticizers Determined by Rheological Tests for Self Compacting Concrete", Periodica Polytechnica Civil Engineering, 62(2), pp. 346-352, 2018. https://doi.org/10.3311/PPci.11247

[14] Sainz-Aja, J., Carrascal, I., Polanco, J. A., Thomas, C., Sosa, I., Casado, J., Diego, S. "Self-compacting recycled aggregate concrete using out-of-service railway superstructure wastes", Journal of Cleaner Production, 230, pp. 945-955, 2019. https://doi.org/10.1016/j.jclepro.2019.04.386

[15] Gill, A. S., Siddique, R. "Durability properties of self-compacting concrete incorporating metakaolin and rice husk ash", Construction and Building Materials, 176, pp. 323-332, 2018. https://doi.org/10.1016/j.conbuildmat.2018.05.054

[16] Alyamaç, K. E., Ince, R. "A preliminary concrete mix design for SCC with marble powders", Construction and Building Materials, 23(3), pp. 1201-1210, 2009.

https://doi.org/10.1016/j.conbuildmat.2008.08.012

[17] Zhu, W., Gibbs, J. C., Bartos, P. J. M. "Uniformity of in situ properties of self-compacting concrete in full-scale structural elements", Cement and Concrete Composites, 23(1), pp. 57-64, 2001. https://doi.org/10.1016/S0958-9465(00)00053-6

[18] Khayat, K. H., Tremblay, S., Paultre, P. "Structural response of self-consolidating concrete columns", In: Proceedings of the First International RILEM Symposium on Self-Compacting Concrete, Stockholm, Sweden, 1999, pp. 291-306.

[19] Sonebi, M., Tamimi, A. K., Bartos, P. J. M. "Performance and Cracking Behavior of Reinforced Beams Cast with SelfConsolidating Concrete", ACI Materials Journal, 100(6), pp. 492500,2003

https://doi.org/10.14359/12956

[20] Zhu, W., Bartos, P. J. M. "Permeation properties of self-compacting concrete", Cement and Concrete Research, 33(6), pp. 921-926, 2003.

https://doi.org/10.1016/S0008-8846(02)01090-6

[21] Persson, B. "Internal frost resistance and salt frost scaling of self-compacting concrete", Cement and Concrete Research, 33(3), pp. 373-379, 2003. https://doi.org/10.1016/S0008-8846(02)00968-7

[22] Ponikiewski, T., Gołaszewski, J. "The influence of high-calcium fly ash on the properties of fresh and hardened self-compacting concrete and high performance self-compacting concrete", Journal of Cleaner Production, 72, pp. 212-221, 2014. https://doi.org/10.1016/j.jclepro.2014.02.058

[23] Ramezanianpour, A. A., Khazali, M. H., Vosoughi, P. "Effect of steam curing cycles on strength and durability of SCC: A case study in precast concrete", Construction and Building Materials, 49, pp. 807-813, 2013.

https://doi.org/10.1016/j.conbuildmat.2013.08.040
[24] Nehdi, M., Pardhan, M., Koshowski, S. "Durability of selfconsolidating concrete incorporating high-volume replacement composite cements", Cement and Concrete Research, 34(11), pp. 2103-2112, 2004.

https://doi.org/10.1016/j.cemconres.2004.03.018

[25] Dehwah, H. A. F. "Corrosion resistance of self-compacting concrete incorporating quarry dust powder, silica fume and fly ash", Construction and Building Materials, 37, pp. 277-282, 2012. https://doi.org/10.1016/j.conbuildmat.2012.07.078

[26] Siddique, R. "Compressive strength, water absorption, sorptivity, abrasion resistance and permeability of self-compacting concrete containing coal bottom ash", Construction and Building Materials, 47, pp. 1444-1450, 2013. https://doi.org/10.1016/j.conbuildmat.2013.06.081

[27] Calado, C., Camões, A., Monteiro, E., Helene, P., Barkokébas, Jr., B. "Durability Indicators Comparison for SCC and CC in Tropical Coastal Environments", Materials, 8(4), pp. 1459-1481, 2015. https://doi.org/10.3390/ma8041459

[28] Rao, S., Silva, P., de Brito, J. "Experimental study of the mechanical properties and durability of self-compacting mortars with nano materials $\left(\mathrm{SiO}_{2}\right.$ and $\left.\mathrm{TiO}_{2}\right)$ ", Construction and Building Materials, 96, pp. 508-517, 2015.

https://doi.org/10.1016/j.conbuildmat.2015.08.049

[29] da Silva, P. R., de Brito, J. "Durability performance of self-compacting concrete (SCC) with binary and ternary mixes of fly ash and limestone filler", Materials and Structures/Materiaux et Constructions, 49, pp. 2749-2766, 2016. https://doi.org/10.1617/s11527-015-0683-6

[30] Nielsen, E. P., Geiker, M. R. "Chloride diffusion in partially saturated cementitious material", Cement and Concrete Research, 33(1), pp. 133-138, 2003. https://doi.org/10.1016/S0008-8846(02)00939-0

[31] Ghods, P., Chini, M., Alizadeh, R., Hoseini, M., Shekarchi, M., Ramezanianpour, A. A. "The effect of different exposure conditions on the chloride diffusion into concrete in the Persian Gulf region", In: ConMat ' 05 - the Third International Conference on Construction Materials: Performance, Innovations and Structural Implications and Mindess Symposium, Vancouver, Canada, 2005, Article No: 272.

[32] Lin, G., Liu, Y., Xiang, Z. "Numerical modeling for predicting service life of reinforced concrete structures exposed to chloride environments", Cement and Concrete Composites, 32(8), pp. 571$579,2010$.

https://doi.org/10.1016/j.cemconcomp.2010.07.012

[33] Wang, X.-Y., Lee, H.-S. "Modeling of chloride diffusion in concrete containing low-calcium fly ash", Materials Chemistry and Physics, 138(2-3), pp. 917-928, 2013.

https://doi.org/10.1016/j.matchemphys.2012.12.085

[34] Ryan, P. C., O'Connor, A. J. "Probabilistic analysis of the time to chloride induced corrosion for different Self-Compacting Concretes", Construction and Building Materials, 47, pp. 1106-1116, 2013. https://doi.org/10.1016/j.conbuildmat.2013.05.110

[35] Kim, J., McCarter, W. J., Suryanto, B., Nanukuttan, S., Basheer, P. A. M., Chrisp, T. M. "Chloride ingress into marine exposed concrete: A comparison of empirical- and physically-based models", Cement and Concrete Composites, 72, pp. 133-145, 2016. https://doi.org/10.1016/j.cemconcomp.2016.06.002 
[36] Taheri-Motlagh, A. "Durability of Reinforced Concrete Structures in Aggressive Marine Environment", PhD Thesis, Delft University of Technology, 1998. [online] Available at: https://repository.tudelft.nl/ islandora/object/uuid\%3Ada667178-6acb-449d-a89a-bf6a6b5f6e3d

[37] Shekarchi, M., Rafiee, A., Layssi, H. "Long-term chloride diffusion in silica fume concrete in harsh marine climates", Cement and Concrete Composites, 31(10), pp. 769-775, 2009. https://doi.org/10.1016/j.cemconcomp.2009.08.005

[38] Dousti, A., Rashetnia, R., Ahmadi, B., Shekarchi, M. "Influence of exposure temperature on chloride diffusion in concretes incorporating silica fume or natural zeolite", Construction and Building Materials, 49, pp. 393-399, 2013.

https://doi.org/10.1016/j.conbuildmat.2013.08.086

[39] Valipour, M., Pargar, F., Shekarchi, M., Khani, S., Moradian, M. "In situ study of chloride ingress in concretes containing natural zeolite, metakaolin and silica fume exposed to various exposure conditions in a harsh marine environment", Construction and Building Materials, 46, pp. 63-70, 2013.

https://doi.org/10.1016/j.conbuildmat.2013.03.026

[40] van der Zanden, A. J. J., Taher, A., Arends, T. "Modelling of water and chloride transport in concrete during yearly wetting/drying cycles", Construction and Building Materials, 81, pp. 120-129, 2015.

https://doi.org/10.1016/j.conbuildmat.2015.02.012

[41] ASTM "SASTM C150/C150M - 11 tandard Specification for Portland Cement", ASTM International, West Conshohocken, PA, USA, 2011.

https://doi.org/10.1520/C0150_C0150M-11

[42] ASTM "ASTM C33/C33M - 13 Standard Specification for Concrete Aggregates", ASTM International, West Conshohocken, PA, USA, 2003.

https://doi.org/10.1520/C0033_C0033M-13

[43] ASTM "ASTM C494/C494M - 99a Standard Specification for Chemical Admixtures for Concrete", ASTM International, West Conshohocken, PA, USA, 1999. https://doi.org/10.1520/C0494_C0494M-99A

[44] NORDTEST "NT BUILD 443Concrete, Hardened: Accelerated Chloride", Taastrup, Denmark, 1995.

[45] Iran Meteorological Organization [online] Available at: www. weather.ir

[46] Alizadeh, A. R. "Effect of Curing Conditions on the Chloride Diffusion in Concrete in Persian Gulf", MSc Thesis, University of Tehran, 2004. (in Persian)
[47] ASTM "ASTM C1152/C1152M - 04(2012)e1 Standard Test Method for Acid-Soluble Chloride in Mortar and Concrete", ASTM International, West Conshohocken, PA, USA, 2012. https://doi.org/10.1520/C1152_C1152M-04R12E01

[48] ASTM "ASTM C114 - 07 Standard test methods for chemical analysis of hydraulic cement", ASTM International, West Conshohocken, PA, USA, 2007. https://doi.org/10.1520/C0114-07

[49] Shayanfar, M. A., Barkhordari, M. A., Ghanooni-Bagha, M. "Estimation of Corrosion Occurrence in RC Structure Using Reliability Based PSO Optimization", Periodica Polytechnica Civil Engineering, 59(4), pp. 531-542, 2015. https://doi.org/10.3311/PPci.7588

[50] Wu, L., Li, W., Yu, X. "Time-dependent chloride penetration in concrete in marine environments", Construction and Building Materials, 152, pp. 406-413, 2017.

https://doi.org/10.1016/j.conbuildmat.2017.07.016

[51] Yang, L. F., Cai, R., Yu, B. "Investigation of computational model for surface chloride concentration of concrete in marine atmosphere zone", Ocean Engineering, 138, pp. 105-111, 2017.

https://doi.org/10.1016/j.oceaneng.2017.04.024

[52] Ehlen, M. A., Thomas, M. D. A, Bentz, E. "Life-365 Service Life Prediction ModelTM", Version 2.0, Concrete International, 31(5), pp. 41-46, 2009. [pdf] Available at: http://www.life-365.org/ images/ci3105ehlen_life365.pdf

[53] Mahima, S., Moorthi, P. V. P., Bahurudeen, A., Gopinath, A. "Influence of chloride threshold value in service life prediction of reinforced concrete structures", Sādhanā, 43, Article number: 115, 2018.

https://doi.org/10.1007/s12046-018-0863-5

[54] Sawicz, Z., Heng, S. S. "Durability of concrete with addition of limestone powder", Magazine of Concrete Research, 48(175), pp. 131-137, 1996.

https://oi.org/10.1680/macr.1996.48.175.131

[55] Ghafoori, N., Spitek, R., Najimi, M. "Influence of limestone size and content on transport properties of self-consolidating concrete", Construction and Building Materials, 127, pp. 588-595, 2016. https://doi.org/10.1016/j.conbuildmat.2016.10.051

[56] Ramezanianpour, A. A., Ghiasvand, E., Nickseresht, I., Mahdikhani, M., Moodi, F. "Influence of various amounts of limestone powder on performance of Portland limestone cement concretes", Cement and Concrete Composites, 31(10), pp. 715-720, 2009. https://doi.org/10.1016/j.cemconcomp.2009.08.003 